\title{
INFORMATION TECHNOLOGY IN THE FUNCTION OF ENVIRONMENTAL EDUCATION OF VOCATIONAL SCHOOL STUDENTS
}

\author{
Vladimir Matic \\ Vocational School Vukovar, Croatia \\ vladimir.matic@vu.t-com.hr
}

\begin{abstract}
Summary - Ecological education of youth, especially students in vocational school at the level of secondary education, by using computers and other information technologies (IT) is relatively new and still area unexplored enough. A survey conducted by the author of this study showed that the use of these technologies can remove the whole series of weaknesses that characterize traditional environmental education of vocational schools students. Traditional education involves teaching environment that is based on the classic lecture. The main goal of such education is the knowledge transfer from teacher to student, where the teacher is the source of knowledge, and the student is a passive recipient. Contemporary education, however, involves not only simple knowledge reproduction, but creates conditions for active involvement of students in the process of acquiring and learning, where different sources are being used. Using modern IT allows students to choose their source of information, but also to adapt to the dynamics of learning to their own intellectual capabilities.
\end{abstract} methods

Key words: computer, IT, teaching,

\section{INTRODUCTION}

National Teaching Standard of Secondary Education in the Republic of Croatia ("Narodne novine", no. 63/08. and no. 90/10.) regulates the unique requirements for a quality educational work and successful achievement of the goals and tasks in secondary schools. Spatial conditions for conducting vocational programs do not prescribe multimedia classrooms, but they impose computer labs equipped with a computer network, server and fifteen computers.

A computer network is an important factor of IT support for environmental education of vocational school students and it is an integral part of the overall multimedia information system. Contemporary environmental education is unimaginable without the Internet. If ecology classes are performed in multimedia classroom, where there are more networked computers, all students have simultaneous Internet access. If the programs consisting environmental content appropriate for vocational educations is used, it is only necessary to be installed to only one computer (the server) so the other students can access it simultaneously. These two examples speak for themselves about the importance of network environment in computer labs.

Software support primarily defines the framework of the possibilities of using computers in the educational process. Compared to conventional teaching resources and aid, computers are intelligent and programmable. This means that educational software has an important role in their application. Quality educational software has to support the active involvement of students in their classes in order to get a computer used as the best learning technique. In this sense, the software must be operational application of knowledge, which will develop the mental creativity of students.

As a result, it is possible to conclude that high-quality and didactically welldesigned education software has to support the following levels of learning:

- Adoption of new teaching facilities (Tutorial),

- Training the routine operations (Drill and Practice) and 
- Teaching dialogue.

Thus, the software clearly defines the use of computers in teaching in all its stages as shown in Figure 1.

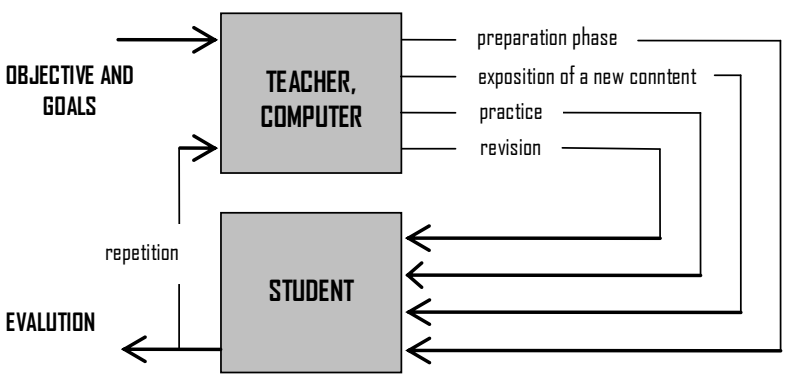

Unfortunately, we have to say that here there are no educational software intended for environmental education, especially for vocational schools, so the

Fig. 1 Lesson phases supported by educational software

teachers are forced to develop ones by themselves. Another option is to get them on the world market and adapt them to their own needs.

In this context, it may be more realistic to expect that the development of quality educational software, which is possible to be implemented in the ecology classes or other classes containing environmental content, will be carried out by ecology teachers themselves, and even to be carriers of this project, where other professionals (IT teachers, sociologists, educators) will also be included.

E-learning includes all forms of electronically supported learning and teaching, which are procedural and aim to influence the construction of knowledge in relation to individual experience, practice and students' knowledge. ICT system, whether networked or not, serve as specific media in the learning process [9].

The basis of communication in this system is provided by a computer with various services. The most famous among them are e-mail, searching and browsing the Internet (Microsoft Explorer, Mozilla Firefox, Netscape).

E-learning allows learning in distance to users so it is often called distance learning, and it became a form of learning used at the most famous universities (Harvard, Stanford). Compared to traditional way of learning, it has many advantages:

- It allows the user to choose the tame and place of learning

- It is time saving

- It allows the user to access to knowledge resources, regardless of the distance (there is the possibility to access from different continents)

- Significantly reduces the cost of learning because at the same time a large number of students can learn which are in the relation to the 'source of knowledge' far away, etc.

The environmental education of vocational schools students can use the various types of distance learning, the most common of which are: e-mail learning, computer simulation and electronic textbooks.

The basic feature of e-mail learning is the fact that educational content is delivered to the student via e-mail. The dynamics of sending is arranged by the teacher and the student and it depends on the dynamics of the individual learning. The environmental education of vocational schools students is a common mode of 
communication in adult education. Communication between teachers and students is done through so called teaching letters created by teachers and are sent to students via e-mail.

Since these letters contain a number of questions for revision, students are obliged to respond to them and return them to the subject teacher.

After being rated by the teacher and if the student has mastered the material of the teaching materials, student is being sent the following letters, sequentially, until the full content prescribed by curriculum and educational programming framework is fully mastered.

Computer simulations, basically, involve the process of imitation (simulation) of certain laws, instances or the events using a computer. It is at the same time the source and the agent in the transfer of information, and its didactic functions may be different, such as exercise, motivation, etc.

Computer simulation provides special computer capabilities in the environmental education of vocational schools students. This is because, among other things, the field of ecology can easily be mathematically modeled (e.g. simulation of pollution of rivers or lakes), and the basis of simulation is a certain pre-selected mathematical and (or) formal-logical model, based on which a simulation algorithm is made [8].

It should be taken into account that the chosen content can be programmed, because programming is an integral part of computer simulations. In addition, it should be the content that students have less knowledge about, because only this way will be possible to determine the effectiveness of the written program.

Many studies in the world and in our country show that students are more and more reading from a computer screen because of the Internet, the global network of computers. One of the possible solutions in e-learning is electronic textbooks for which many publishers and institutions believe to have a bright future.

There are several reasons for this estimation: electronic textbooks are much cheaper, they are more accessible (no need to go to a library or bookstore), there is no problem with borrowed or sold-out editions. One of the major benefits of electronic textbooks in comparison to conventional is the fact that the text can be enriched with audio and video materials, and interactive content, as well. This, in many ways, improves communications with contents that students read.

The most commonly used formats for creating electronic books are PDF, HTML and XML format which are possible to be read by using computer and specially designed reader (e.g. Adobe Acrobat Reader).

The electronic format provides significant other benefits: textbooks can be prepared by the teacher for internal use, combining parts and chapters from different textbooks with their own personal records.

Significant and presently in didactic practice frequently used form of distance learning are streaming media, because they make learning unique and very attractive. Synthesis of audio and visual communication enables the presentation of educational content to generate dynamics and explain in detail, and enables students to follow lectures and exercise, even though they are distant.

In fact, a new technology for the transmission of sound and images in real time enables the realization of along present ideas about creating a virtual classroom $^{31}$, which is the most advanced model of distance learning. Using

\footnotetext{
31 The didactic term of 'virtual clasroom' (Latin virtus - strenght., power) is used as a synonym for the classroom in which, using new technologies and videoconferencing systems, it is possible to realize the audio and video remotely in real time.
} 
videoconferencing system can achieve almost the identical way as in the classical education classroom because it is a model in which the communication takes place entirely synchronous, or in the real time (fig. 2).

Streaming media provide a new quality to distance learning but due to expensive technological solutions and very sophisticated technology, they are far less common than other forms of student education, including the environmental education of students in vocational schools.

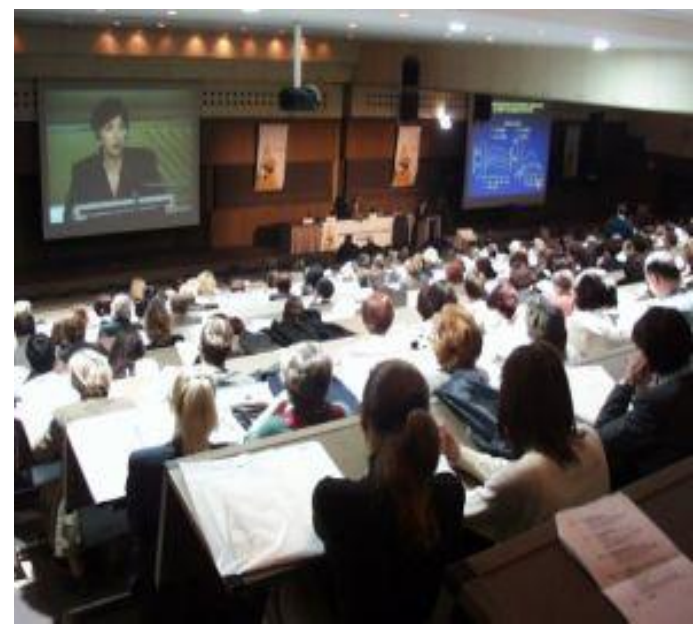

Fig. 2 Videoconferencing hall ${ }^{32}$

The implementation of education software gives distance learning another dimension - new and dynamic form. Quality education software enables students to interact with course content, in other words, working with such software gives them complete control and necessary feedback that significantly affects learning quality and it is precisely for these reasons very suitable for the environmental education of students in vocational schools.

In addition to computers and the Internet, IT supports in the ecological education of vocational school students make other information and communication technologies such as LCD

\footnotetext{
${ }^{32}$ Source:

www.carnet.hr/videokonferencije/primjeri
}

projector, printer, scanner, webcam, digital camera, flexo-camera, microphone, headphones, etc. Quality model of IT support to ecological education of vocational school students is the one in which a teacher accurately defines how, when and to what extent to use computers, educational software, the Internet and other ICTs.

Which IT support will be used is decided among teachers who teach the same subject. Of course, this support can be different from case to case because curriculum contents may differ. It is very important to find the optimal ratio between the classic lecture typical for traditional classes and IT supported, which means that there classic lecture should be combined with adequate IT support.

Table 1 shows the review of teaching materials distribution in various distance learning. 
Table 1 The review of teaching materials distribution in various distance learning

\begin{tabular}{|c|c|c|}
\hline 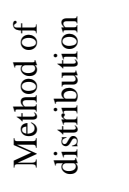 & Characteristics & 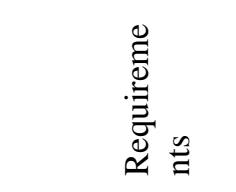 \\
\hline 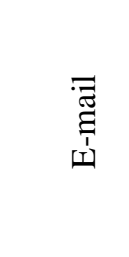 & $\begin{array}{l}\text { Faster way of distribution of teaching material. } \\
\text { Restricted to students who have the Internet and computer } \\
\text { access. } \\
\text { It allows text and graphics sending. } \\
\text { It facilitates more frequent teacher - student communication. }\end{array}$ & 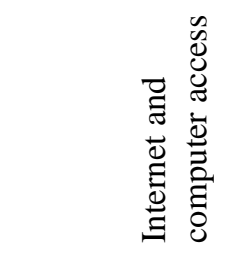 \\
\hline \multirow{2}{*}{ 总事 } & $\begin{array}{l}\text { The usage of greater data resources. } \\
\text { Individuals or groups can access date simultaneously. } \\
\text { It includes the possibility of the usage of active page links } \\
\text { with other pages. }\end{array}$ & 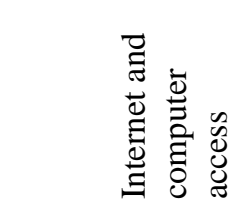 \\
\hline & $\begin{array}{l}\text { Database is frequently updated. } \\
\text { Students have limited data access (security). } \\
\text { Limited simultaneous interaction. }\end{array}$ & 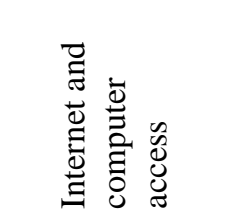 \\
\hline 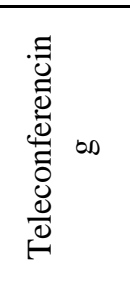 & $\begin{array}{l}\text { It allows one-way or two-way audio or audio-video } \\
\text { communication. } \\
\text { The possibility of individual or group simultaneous } \\
\text { involvement. } \\
\text { Time and space limit. } \\
\text { Complete experience of teaching content }\end{array}$ & 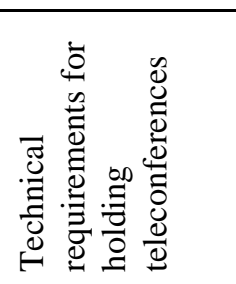 \\
\hline
\end{tabular}

In both domestic and foreign literature the ability of IT support to environmental education of students is not presented enough especially in vocational schools, so this is what motivated the authors of this paper to conduct a study to determine the extent to which IT support to environmental education of students in vocational schools increases the overall efficiency of the teaching process.

\section{METHODS, TECHNIQUES AND INSTRUMENTS}

In this paper, the method of analysis and synthesis, compilation and comparison methods are used.
Basic research techniques are used:

- Literature analysis,

- Testing and interviewing students, and

- Data processing.

In order to sample representativeness, the survey was conducted randomly choosing thirty students from ten different occupational classes in the Vocational School of Vukovar. The methods for statistical data analysis used are: the IDA analysis (Initial Data Analysis), EDA analysis and synthesis.

\section{RESEARCH GOAL}

The main objective of the research is to point the statistically significant ability to 
raise the overall level and quality of environmental education of vocational school students by using modern IT.

Of course, besides the basic, there are also secondary objectives such as:

- To come to scientific knowledge in the extent to which IT support to environmental education of vocational schools students affect the quality and quantity of acquired knowledge

- To reach the exact indicators and insights on the time cost by using IT support to environmental education of vocational school students when compared to traditional teaching

- To examine the extent to which IT support to environmental education affects students in vocational schools to raise their motivation in the learning process

- To establish the extent to which a model of IT support to environmental education of vocational school students respects a wide range of individual abilities of students.

\section{RESEARCH PROGRESS}

The research was conducted on a sample of four occupations in four years duration and four occupations in three year duration. Occupations in duration of four years are: agricultural technicians, nutritionists, hotel and tourism technicians, hotel and tourism business administrators; and occupations in duration of three years are: waiters $U M E^{33}$, cooks UME, hairdressers UME and beauticians UME.

First, we conducted an analysis of the curriculum, in order to determine whether, in addition to teaching ecology, there are

\footnotetext{
${ }^{33}$ UME stands for uniqe model of education in which students of all three-year programs (occupations) have the same general subjects, represented by the same number of lessons.
}

some other subjects containing ecological teaching content. Based on the results of conducted research, we believe that the IT support used in teaching ecology, with some modifications, can be used in teaching these subjects. We separately analyzed the natural and social studies (Table 2 and Table. 3).

Although there is far smaller number of subjects under the social studies whose curricula and educational programs provide a framework of environmental content, they should not be ignored. On the contrary, the model of IT support used in the survey, with minor modifications, can be used in teaching social studies in a way that it is adjusted to program contents of each subject individually. 
Table 2 Overview of natural studies in whose curricula ecological contents are represented

\begin{tabular}{|c|c|c|c|c|c|c|c|c|c|}
\hline \multirow{2}{*}{$\begin{array}{l}\dot{\bar{D}} \\
\text { है } \\
\text { Z }\end{array}$} & \multirow{2}{*}{$\begin{array}{l}\frac{\vec{U}}{0} \\
\frac{0}{0} \\
\bar{\Xi}\end{array}$} & \multicolumn{8}{|c|}{ Program - occupation } \\
\hline & & 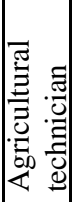 & 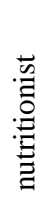 & 点 & 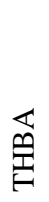 & 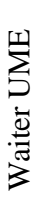 & $\begin{array}{l}\sum_{j}^{1} \\
\vdots \\
\frac{n}{0} \\
0\end{array}$ & 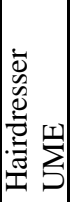 & : \\
\hline 1. & Biologiy & + & + & - & - & - & - & - & - \\
\hline 2. & $\begin{array}{l}\text { Biology } \\
\text { with } \\
\text { ecology }\end{array}$ & - & - & + & - & - & - & - & - \\
\hline 3. & $\begin{array}{l}\text { Biology } \\
\text { with } \\
\text { hygiene } \\
\text { and } \\
\text { ecology }\end{array}$ & - & - & - & + & - & - & - & - \\
\hline 4. & $\begin{array}{c}\text { Ecologica } \\
1 \text { food } \\
\text { productio } \\
n\end{array}$ & - & + & - & - & - & - & - & - \\
\hline 5. & $\begin{array}{l}\text { Safety at } \\
\text { work, } \\
\text { hygiene }\end{array}$ & - & + & - & - & - & - & - & - \\
\hline 6. & $\begin{array}{c}\text { Plant } \\
\text { protection }\end{array}$ & + & - & - & - & - & - & - & - \\
\hline 7. & $\begin{array}{l}\text { Biology } \\
\text { and } \\
\text { ecology }\end{array}$ & - & - & - & - & + & + & - & - \\
\hline 8. & Practice & + & + & + & - & - & - & - & - \\
\hline
\end{tabular}

Table 3. Overview of science studies in whose curricula ecological contents are represented.

\begin{tabular}{|c|c|c|c|c|c|c|c|c|c|}
\hline \multirow[b]{2}{*}{$\begin{array}{l}\overline{\mathrm{D}} \\
\text { 节 } \\
\text { Z }\end{array}$} & \multirow[b]{2}{*}{$\begin{array}{l}\frac{\vec{U}}{0} \\
\frac{.}{0} \\
\ddot{\mathscr{n}}\end{array}$} & \multicolumn{8}{|c|}{ Program - occupation } \\
\hline & & 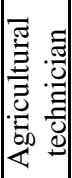 & 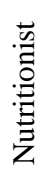 & 㫐 & 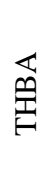 & 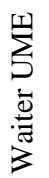 & 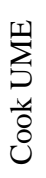 & 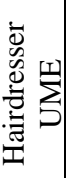 & 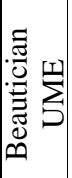 \\
\hline 1. & Ethics & + & + & + & + & + & + & + & + \\
\hline
\end{tabular}




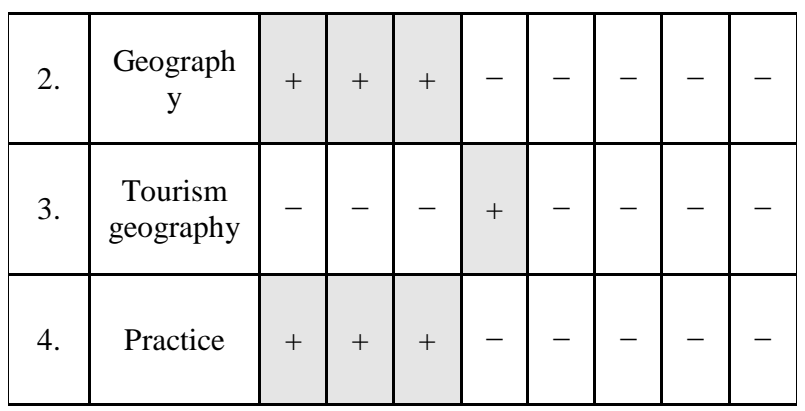

The research was conducted in two directions. One part of the examinees attended a lecture from one teaching unit (POLLUTION AND ENVIRONMENT PROTECTION) in the traditional classroom, where classes are held in the traditional way. Another part of the examinees attended the same subject teaching unit processed independently and in multimedia classroom (computer lab) using the author's application which is an interactive ecology textbook (fig. 3.) with the ability to access the Internet and use of already mentioned IT.

Microsoft Visual Studio 2008 and ASP.NET Framework 3.5. platforms are used to create a model of interactive multimedia ecology textbook. The application was developed as a web page in order to make it available to all interested users.

An important characteristic of a multimedia textbook is its interactivity. That is why the textbook has an embedded module for independent testing of students, with the possibility of controlling their own achievement and the level of knowledge, correct and incorrect responses check and test themselves again.

After that, all the participants in the study underwent testing in order to determine if a computer supported ecology lessons are more effective than traditional learning methods. We used the tests with the series of objective type tasks and the testing was conducted the last fifteen minutes of the lesson.

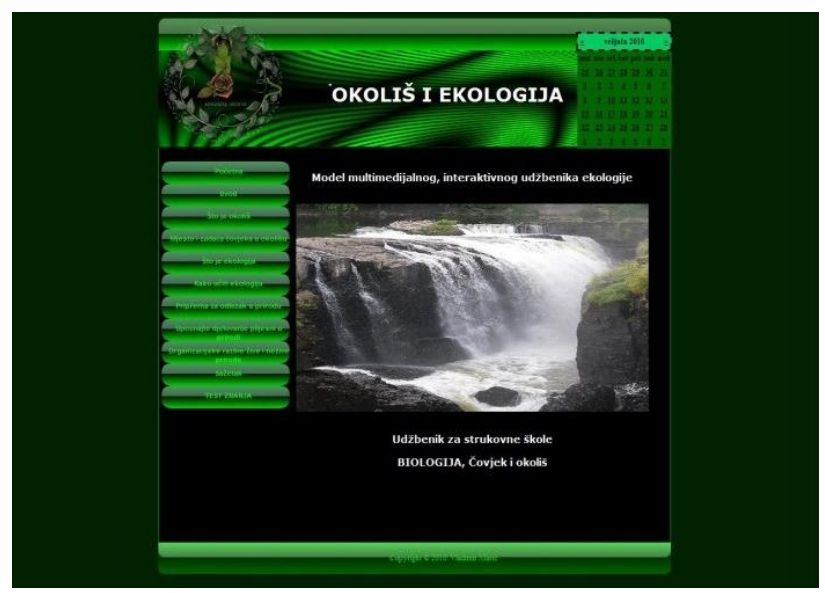

Fig. 3 Homepage

After processing the answers, we found that the processed data are significantly different because the students using IT support achieved far better results in learning new material when compared to traditional way of learning.

In order to prove that the use of modern IT support increases the overall efficiency of the teaching process, the following table 
is presented to show a synthetic view of students', both in traditional and IT supported learning, correct answers only.

Table 4 Synthetic overview of students' correct answers

\begin{tabular}{|c|c|c|c|c|}
\hline Question & $\mathrm{Tr}$ & ITs & $\operatorname{Tr}[\%]$ & ITs[\%] \\
\hline 1. & 12 & 18 & 40,00 & 60,00 \\
\hline 2. & 10 & 20 & 33,33 & 66,67 \\
\hline 3. & 13 & 17 & 43,33 & 56,67 \\
\hline 4. & 12 & 18 & 40,00 & 60,00 \\
\hline 5. & 12 & 18 & 40,00 & 60,00 \\
\hline 6. & 12 & 18 & 40,00 & 60,00 \\
\hline 7. & 16 & 14 & 53,33 & 46,67 \\
\hline 8. & 10 & 20 & 33,33 & 66,67 \\
\hline 9. & 15 & 15 & 50,00 & 50,00 \\
\hline 10. & 11 & 19 & 36,67 & 63,33 \\
\hline 11. & 10 & 20 & 33,33 & 66,67 \\
\hline 12. & 12 & 18 & 40,00 & 60,00 \\
\hline Question & $\operatorname{Tr}$ & ITs & $\operatorname{Tr}[\%]$ & ITs [\%] \\
\hline 13. & 10 & 20 & 33,33 & 66,67 \\
\hline 14. & 13 & 17 & 43,33 & 56,67 \\
\hline 15. & 14 & 16 & 46,67 & 53,33 \\
\hline
\end{tabular}

Comparative data analysis shows that the use of IT learning is far more effective than traditional. Of the total of 30 subjects on which the survey was conducted, 11 students $(40.44 \%)$ learning in the traditional way answered correctly.
In the IT supported learning way, the number is higher. Correct answers were given by 19 students $(59.56 \%)$, which lead us to a conclusion that the IT supported way of learning is more efficient than traditional methods, i.e. used ITs increase the overall efficiency of the teaching process (Fig. 4). 


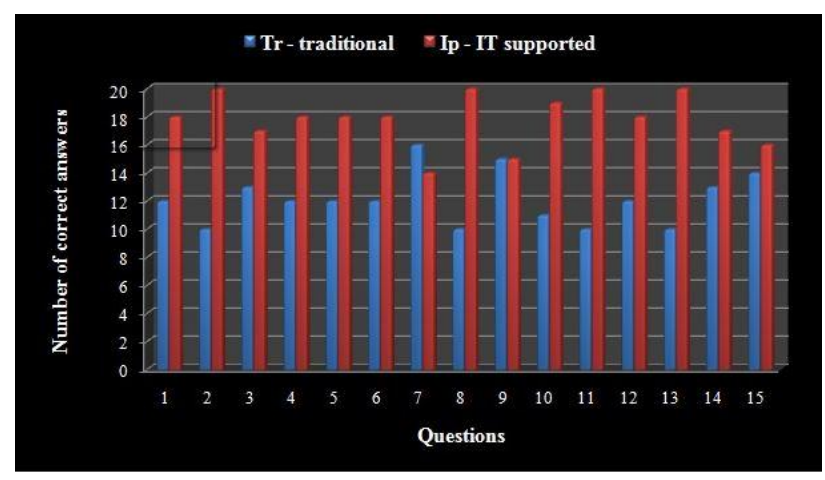

Fig. 4 Graphic display of correct answers in traditional and IT supported learning.

\section{CONCLUSION}

An important influence on the development of education throughout the history of mankind have the technological breakthroughs that can be applied in the teaching process and thus make it more efficient. The beginning of the $20^{\text {th }}$ century is marked by the application of modern ITs, where traditional teaching gradually loses its original meaning.

The basic problem, which was the subject of conducted research, is to determine the role of IT in the environmental education of students in vocational schools, i.e. to prove that the use of IT in teaching increases the overall efficiency of the teaching process.

Testing and measuring of relevant parameters affecting the efficiency of this way of learning are carried out in this research. Measurements of the relevant parameters and the analysis of the results were performed using standard statistical method.

The most significant scientific contribution to the research is a set of formal specification of educational and ICT methods which can be a support to traditional education, as well as the evidence of better qualitative and quantitative results in mastering the curriculum in IT supported ecology classes and other subjects containing ecological content.
When the Internet as a global network of computers appeared, it became a medium of global communication and virtually limitless resource of teaching contents, including ecology. Basic and secondary research objectives are achieved by scientific knowledge about the quality and quantity of application level of traditional and IT methods for the purpose of environmental education of the students in vocational schools.

In the experimental part of the study, a model of interactive multimedia ecology textbook is used and it was developed by the author of the work combining a part of a biology textbook for first and second grade students [10], which discusses the ecological content with personal notes and records of biology teacher, experiments done in the school laboratory and nature, as well as the video and audio files.

\section{REFERENCES}

[1] S. Alessi and S. Trollip, "Multimedia for Learning", Massachusetts: Allyn and Bacon, Pearson Publishing Company, 2001.

[2] R. C. Clark and R. Mayer, "E-Learning and science of Instruction", San Francisco: Pfeiffer, 2001.

[3] R. Marinković, "Inteligentni sustavi za poučavanje", Zagreb: Hrvatska zajednica tehničke kulture, 2004.

[4] V. Matić, "Model informatičke podrške ekološkom obrazovanju učenika strukovnih škola", doktorska disertacija, Zrenjanin: Tehnički fakultet "Mihajlo Pupin", 2011. 
[5] V. Matić, P. Hotomski i K. Voskresenski, "Personal computer in use of ecological education pupils vocational schools", Technics Technologies Education Management, vol. 6 (4), pp. 1188-1198, Sarajevo: DRUNPP, 2011.

[6] V. Matić, "Environmental Education of Students in Vocational Schools in a Multimedia Surrounding", IEEE $35^{\text {th }}$ international convention, ISSN: 1847-3946, pp. 1527-1532, Opatija: May 21-25, 2012.

[7] M. Matijević i L. Bognar, "Didaktika", Zagreb: Školska knjiga, 1974.

[8] S. Rodek, "Kompjutor i suvremena nastavna tehnologija", Zagreb: Školska knjiga, 1986.

[9] E. Tobolka, "Model računarski podržane nastave engleskog jezika i metode njene realizacije kao faktor unapređenja i informatizacije obrazovanja", Zrenjanin: Tehnički fakultet "Mihajlo Pupin", 2002.

[10] Lj. Vrček, "Biologija, udžbenik za strukovne škole, svezak C", Zagreb: Profil, 2007 